\title{
Importance of Hydrogen Migration in Catalytic Ammonia Synthesis over Yttrium-doped Barium Zirconate Supported Ruthenium Nanoparticles: Visualization of Proton Trap Sites
}

Christopher Foo ${ }^{1,2 \square}$, Joshua Fellowes, ${ }^{1 \square}$, Huihuang Fangl, Alexander Large, ${ }^{2}$ Simson $W u,{ }^{1}$ Georg Held, ${ }^{2}$ Elizabeth Raine ${ }^{1}$, Ping-Luen Ho ${ }^{1}$, Chiu Tang ${ }^{2}$, and Shik Chi Edman Tsang ${ }^{1 *}$

$\square$ Authors contributed equally to the work. as co-first authors.

*Corresponding author email: edman.tsang@chem.ox.ac.uk

${ }^{1}$ Wolfson Catalysis Centre, Department of Chemistry University of Oxford, Oxford, OXI 3QR, UK

${ }^{2}$ Diamond Light Source, Didcot, OX11 ODE, UK

\section{Supporting Information}




\section{Figures and Tables}

\section{$\underline{\text { TEM }}$}


Figure S1. TEM micrographs of the supports (L) Ru-BZEr20, and (R) Ru-BZY20.

$\underline{\text { X-ray Diffraction }}$

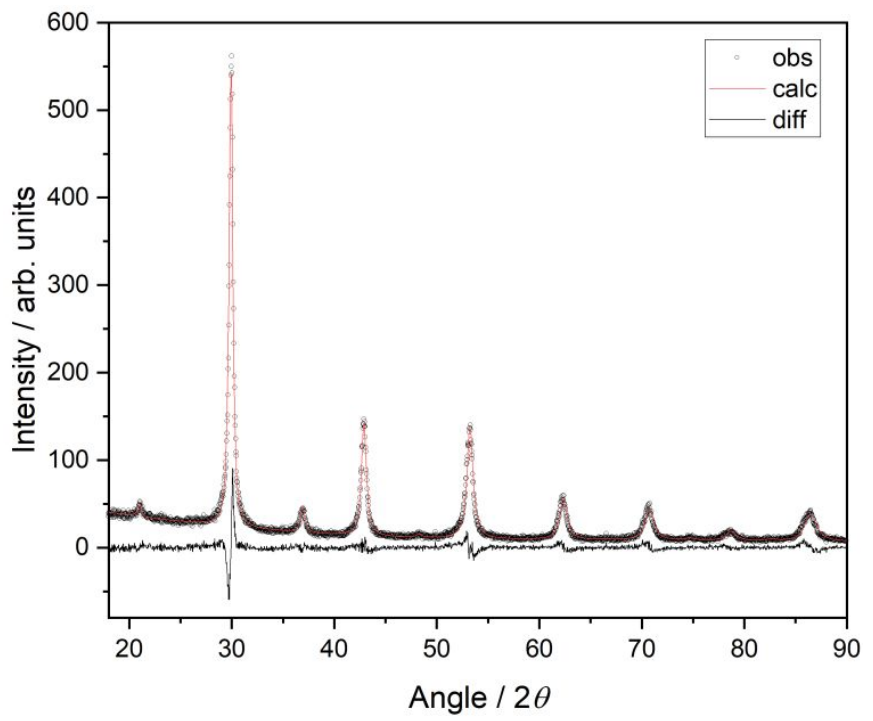

Figure S2. Pawley fitting of pristine BZY20 as an example of a typical fitting $\left(R_{\mathrm{wp}}=11.3\right)$. 


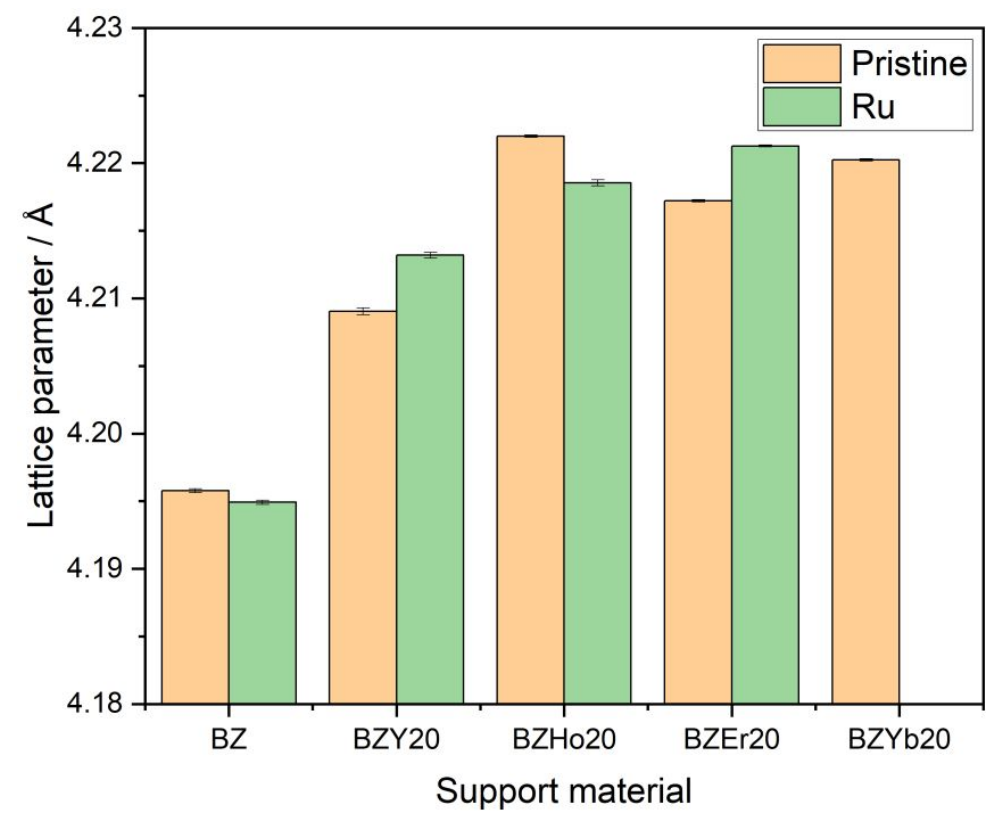

Figure S3. Lattice parameters yielded by Pawley refinement of laboratory-source XRD patterns of the pristine and ruthenium-loaded support materials. Standard deviation expressed as error bars. 


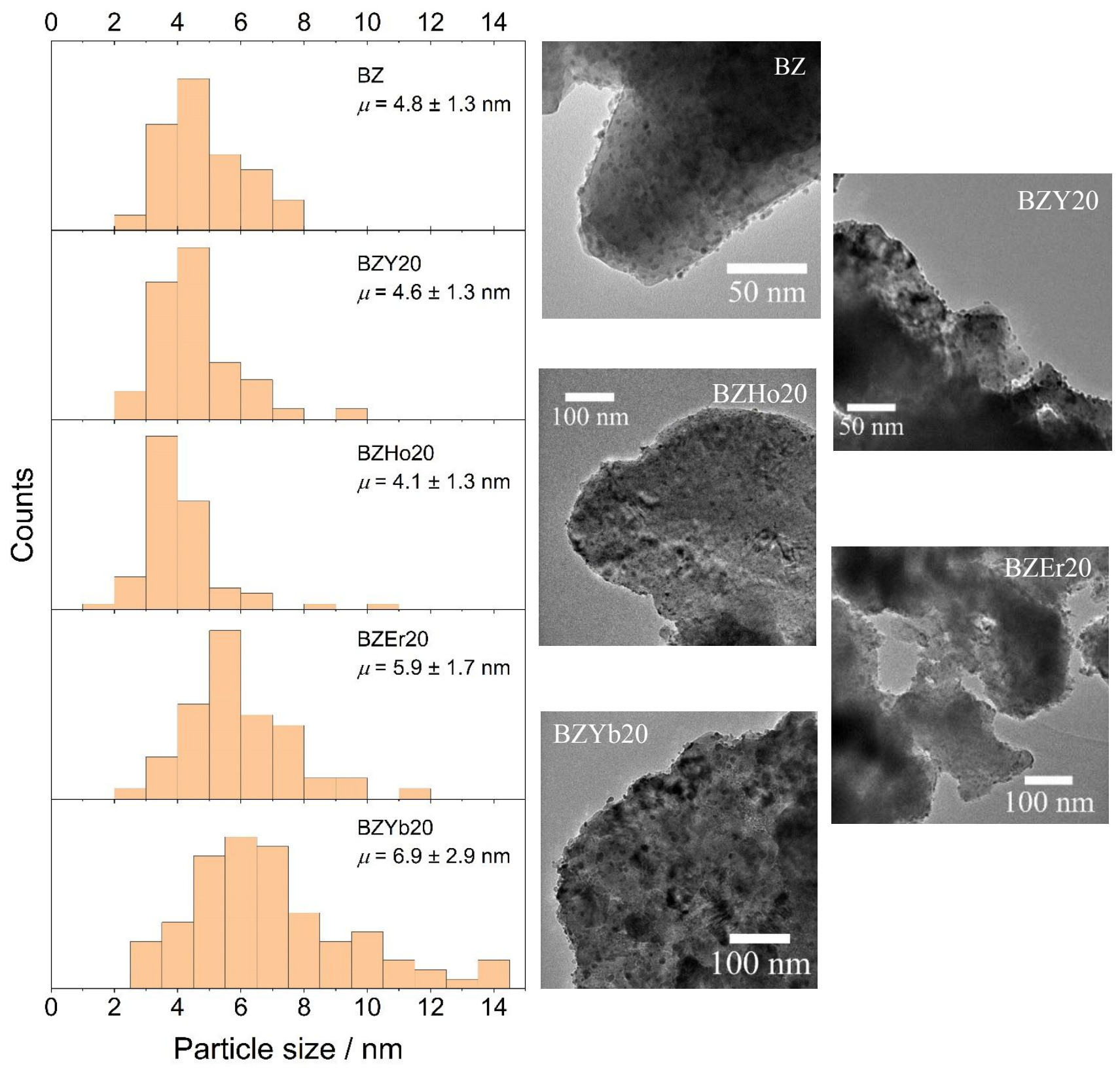

Figure S4. Histograms of ruthenium particle size measurements taken from 50 measurements across multiple micrographs for each sample. 

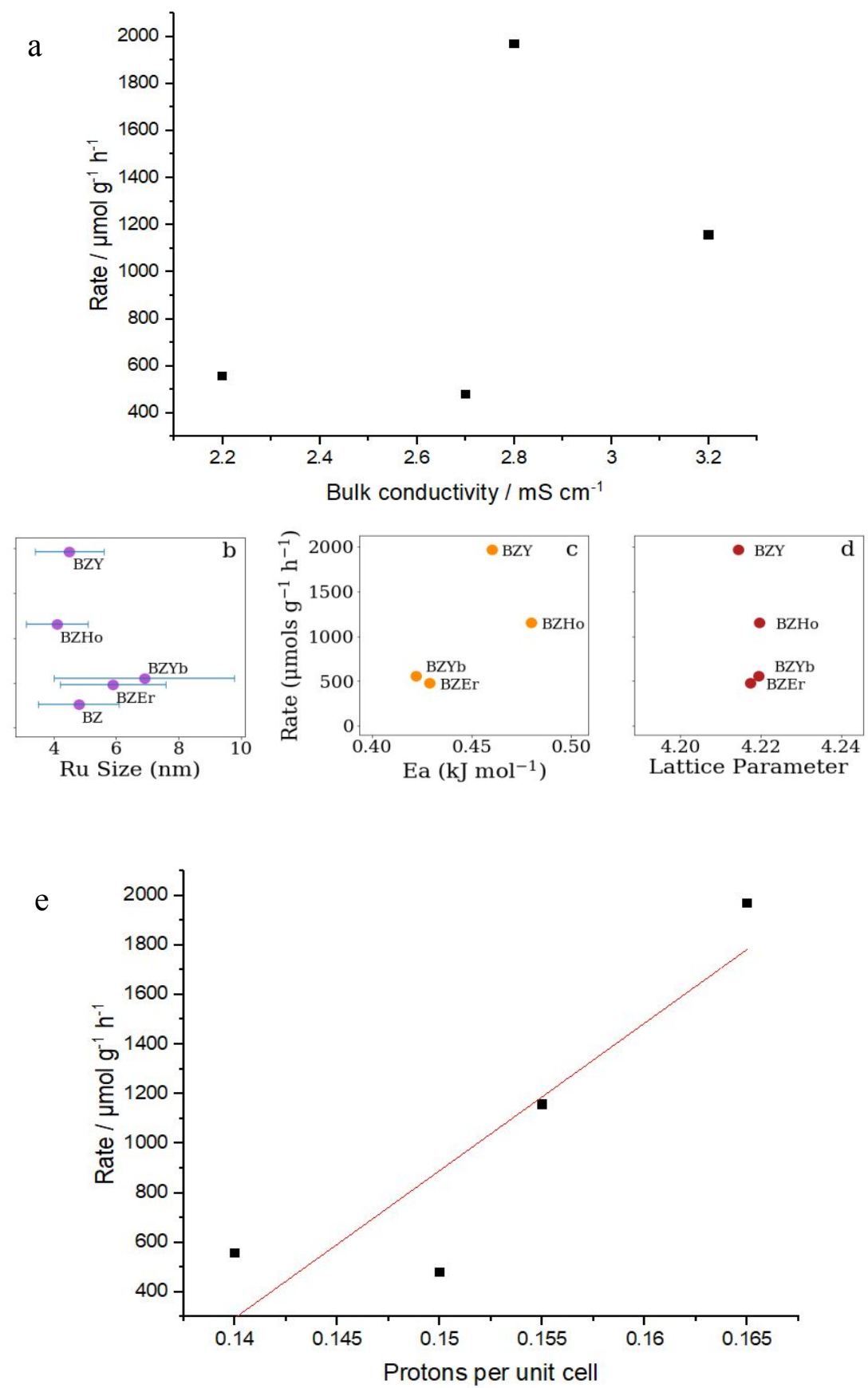

Figure S5. The rates of ammonia synthesis of the four rare-earth-doped BZ samples have no direct correlation with (a) bulk proton conductivity, (b) ruthenium nanoparticle size, (c) proton transport activation energy, (d) lattice parameter. However, there appears to be better correlation with their proton concentration. Non-rate data in (a), (c), and (e) from ref. ${ }^{1}$.

Proton conductivity can be in functions of many factors such as sample crystallinity, grain boundaries, and more importantly oxygen vacancies and trapped sites etc. As seen from Fig. S5 that there is a good correlation of rate of ammonia production to their proton concentration per unit cell where $\mathrm{Y}$ shows the highest value. 

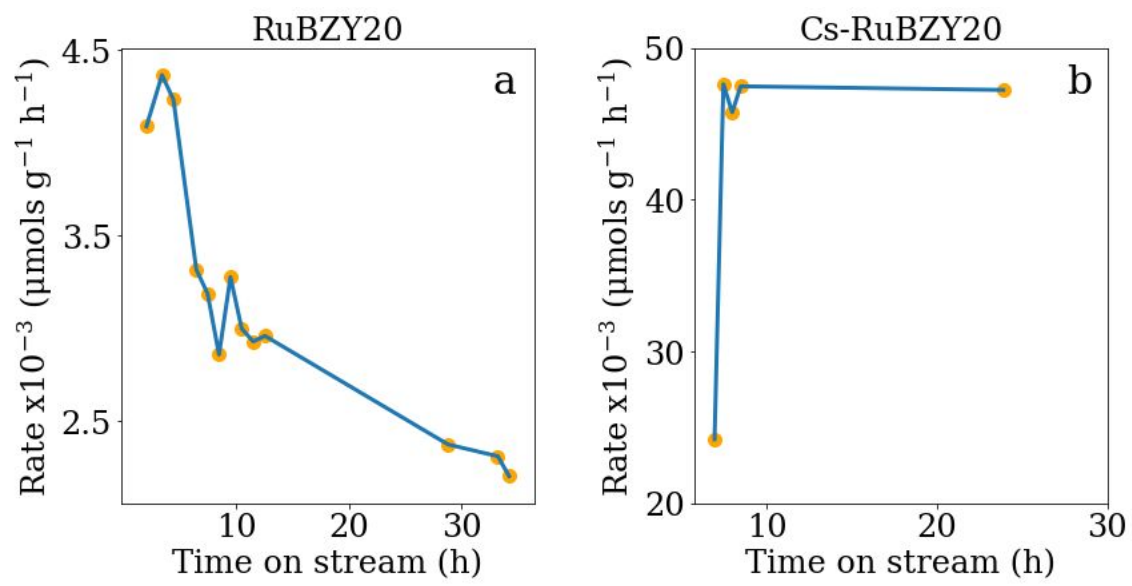

Figure S6. Comparison of (a) RuBZY20 over 34 hours, and (b) Cs-RuBZY20 over 24 hours.

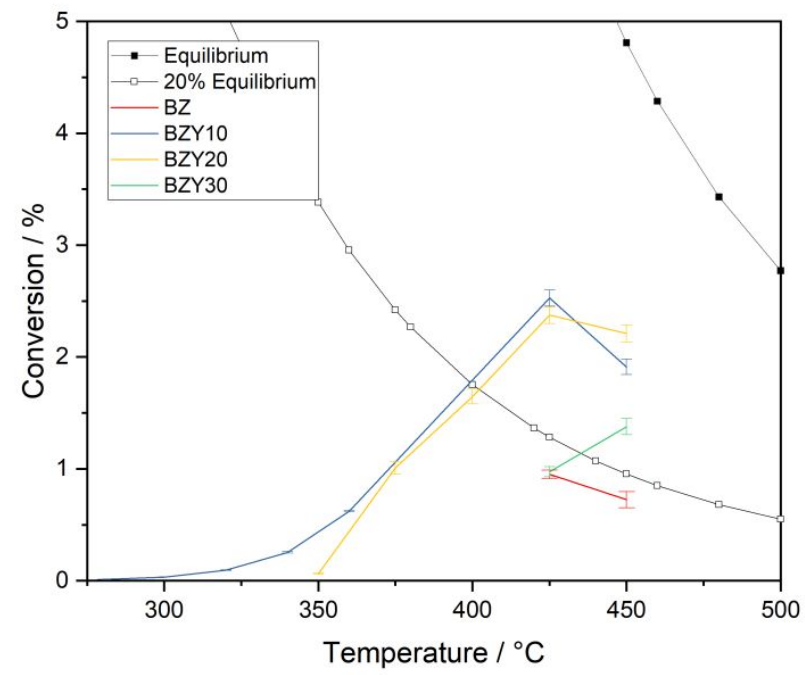

Figure S7. Conversion of feedstock against temperature. Error bars represent standard deviation from at least three rate measurements. Conversion at thermal equilibrium and 20\% equlibrium calculated using FactSage software. All experiments carried out with $0.1 \mathrm{~g}$ catalyst, $3: 1 \mathrm{H}_{2}: \mathrm{N}_{2}$, GHSV $=12,400 \mathrm{~h}^{-1}$.

The rates of reaction observed at or beyond $450^{\circ} \mathrm{C}$ are considered to be limited by back-reaction. It is important to acknowledge that these measurements are still valid observations. It is true that unexpectedly low hydrogen-orders at temperatures approaching equilibrium could be attributed to 'equilibrium-limiting hydrogen-poisoning'; however, only high orders are observed. So, it is acknowledged 
that at high temperatures the observed rate of reaction will be being significantly repressed by backward reaction, resulting in a minimum activity that is some fraction of the non-equilibrium limited activity.
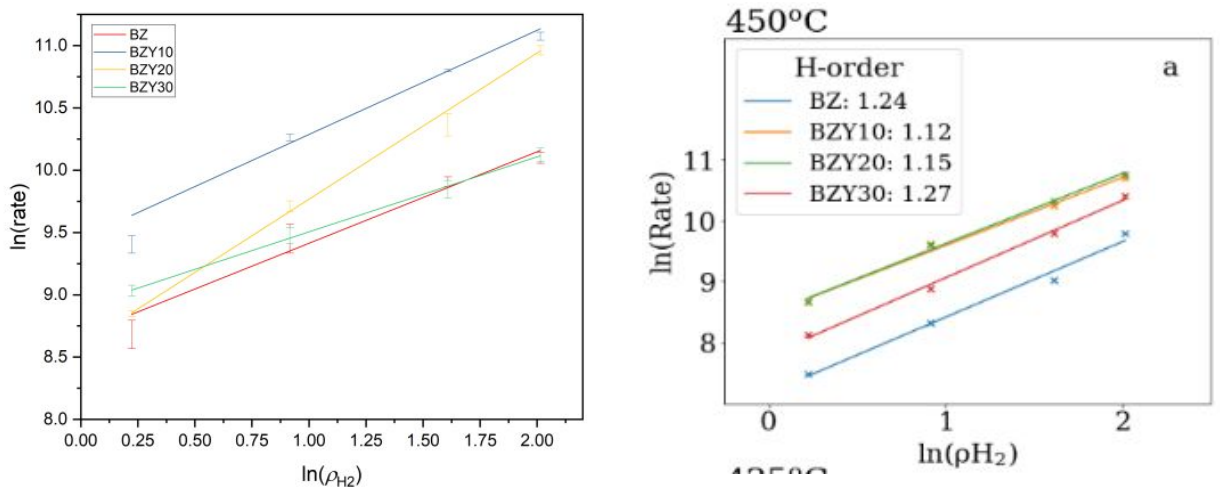

Figure S8. Kinetic analysis of Cs-RuBZY catalysts at (a) $425^{\circ} \mathrm{C}$ and (b) $450^{\circ} \mathrm{C}$. 
Comparison to literature performance

\begin{tabular}{|c|c|c|c|c|c|c|}
\hline Catalyst & $\begin{array}{c}\text { Ru } \\
\text { wt. } \%\end{array}$ & $\begin{array}{c}\text { Temperature } \\
/{ }^{\circ} \mathrm{C}\end{array}$ & $\begin{array}{c}\text { WHSV /mL } \\
\mathbf{h}^{-1} \mathbf{g}^{-1}\end{array}$ & $\begin{array}{c}\text { Rate } / \mu \text { mol } \\
g^{-1} h^{-1}\end{array}$ & $\begin{array}{l}\text { Rate /mol } \\
\text { mol }_{\mathrm{Ru}}{ }^{-1} \mathrm{~h}^{-1}\end{array}$ & Reference \\
\hline$C s-R u / B Z Y 10$ & 10 & 360 & 120,000 & 14,100 & 14.2 & This work \\
\hline$C s-R u / B Z Y 20$ & 10 & 375 & 120,000 & 22,900 & 23.1 & This work \\
\hline$C s-R u / B Z Y 20$ & 10 & 400 & 120,000 & 37,400 & 37.8 & This work \\
\hline $\mathrm{Ru} / \mathrm{C} 12 \mathrm{~A} 7: \mathrm{e}^{-}$ & 1.2 & 400 & 18,000 & 8200 & 69.1 & $\begin{array}{l}\text { Kitano et al. } \\
2012\end{array}$ \\
\hline $\mathrm{Ru}-\mathrm{Ba} / \mathrm{AC}$ & 9.1 & 400 & 18,000 & 8300 & 9.2 & $\begin{array}{l}\text { Kitano et al. } \\
2012\end{array}$ \\
\hline $\mathrm{Ru}-\mathrm{Cs} / \mathrm{MgO}$ & 6.0 & 400 & 18,000 & 12,100 & 20.4 & $\begin{array}{l}\text { Kitano et al. } \\
2012\end{array}$ \\
\hline $\mathrm{Ru} / \mathrm{BaZrO}_{3}{ }^{(\mathrm{a})}$ & 4 & 375 & $\left(10,000 \mathrm{~h}^{-1}\right)$ & 10,200 & 25.8 & $\begin{array}{l}\text { Wang et al. } \\
2013\end{array}$ \\
\hline $\mathrm{Ru} / \mathrm{BaZrO}_{3}{ }^{(\mathrm{a})}$ & 4 & 400 & $\left(10,000 \mathrm{~h}^{-1}\right)$ & 15,300 & 38.7 & $\begin{array}{l}\text { Wang et al. } \\
2013\end{array}$ \\
\hline $\mathrm{Ru} / \mathrm{Pr}_{2} \mathrm{O}_{3}$ & 5 & 400 & 18,000 & 19,000 & 38.4 & $\begin{array}{c}\text { Sato et al. } \\
2016\end{array}$ \\
\hline Co-LiH & - & 350 & 60,000 & 11,500 & - & $\begin{array}{l}\text { Wang et al. } \\
2017\end{array}$ \\
\hline $\mathrm{Fe}-\mathrm{LiH}$ & - & 350 & 60,000 & 10,800 & - & $\begin{array}{l}\text { Wang et al. } \\
2017\end{array}$ \\
\hline $\mathrm{Ru} / \mathrm{BZY} 10$ & 2 & 400 & 36,000 & 4,000 & 20.2 & $\begin{array}{c}\text { Shimoda et al. } \\
2017\end{array}$ \\
\hline $\mathrm{Ru} / \mathrm{La}_{0.5} \mathrm{Ce}_{0.5} \mathrm{O}_{1.75}{ }^{(\mathrm{b})}$ & 5 & 400 & 72,000 & 65,000 & 131.4 & $\begin{array}{c}\text { Ogura et al. } \\
2018\end{array}$ \\
\hline $\mathrm{Ru} / \mathrm{La}_{0.5} \mathrm{Ce}_{0.5} \mathrm{O}_{1.75}{ }^{(\mathrm{b})}$ & 5 & 350 & 72,000 & 32,000 & 64.7 & $\begin{array}{c}\text { Ogura et al. } \\
2018\end{array}$ \\
\hline $\mathrm{Ru} / \mathrm{Ba}-\mathrm{Ca}\left(\mathrm{NH}_{2}\right)_{2}$ & 10 & 360 & 36,000 & 60,000 & 60.6 & $\begin{array}{l}\text { Kitano et al. } \\
2018\end{array}$ \\
\hline $\mathrm{Ru} / \mathrm{CeO}_{2}$ & 10 & 400 & 60,000 & 18,000 & 18.2 & Lin et al. 2018 \\
\hline $\mathrm{Cs}-\mathrm{Ru} / \mathrm{MgO}(111)$ & 3.7 & 400 & 72,000 & 34,300 & 93.7 & Wu et al. 2020 \\
\hline
\end{tabular}

Table S1. Test conditions and ammonia synthesis rates of literature, and investigated catalysts. Literature data taken from references ${ }^{2-10}$ All literature rates are from tests recorded at 3:1 $\mathrm{H}_{2}: \mathrm{N}_{2}$ and at $1.0 \mathrm{MPa}$, except (a) and (b) for which 3.0 MPa and 0.9 MPa were used, respectively. WHSV could not be determined for the $\mathrm{Ru} / \mathrm{BaZrO}_{3}$ catalyst, so the reported GHSV is given instead. ${ }^{4}$ 


\section{Further testing}

The low temperature catalysis of the most active catalyst Cs-RuBZY10 was tested. It is well-researched that the rate determining step of the HB process is the dissociative adsorption of dinitrogen, and would be expected to be verified by an activation energy $\sim 100 \mathrm{~kJ} \mathrm{~mol}^{-1} \cdot{ }^{11,12}$ However, between $280^{\circ} \mathrm{C}$ and $360^{\circ} \mathrm{C}$, the reaction is shown to have an activation energy of $42 \mathrm{~kJ} \mathrm{~mol}^{-1}$ (Figure S7). This value is very low and is more similar to diffusion activated reactions. The value fully agrees with the activation energy found by thermal desorption spectroscopy for the desorption of hydrogen from a loosely bound state that is associated with high overage of hydrogen $\left(42 \mathrm{~kJ} \mathrm{~mol}^{-1}\right)^{13}$. It is proposed that the electron donation from the hydrogen spill-over effect reduces the activation energy for the dissociation of dinitrogen so much that the ratedetermining step becomes the removal of poisonous hydrogen from the ruthenium surface. The value is also similar to DFT calculations of activation energy for the dinitrogen dissociation $\left(35 \mathrm{~kJ} \mathrm{~mol}^{-1}\right)^{14}$. This unexpectedly low value can again be explained by reduced activation energy due to hydrogen spill-over. An even lower activation energy analysis was found for Cs-RuBZY20 at high temperatures.
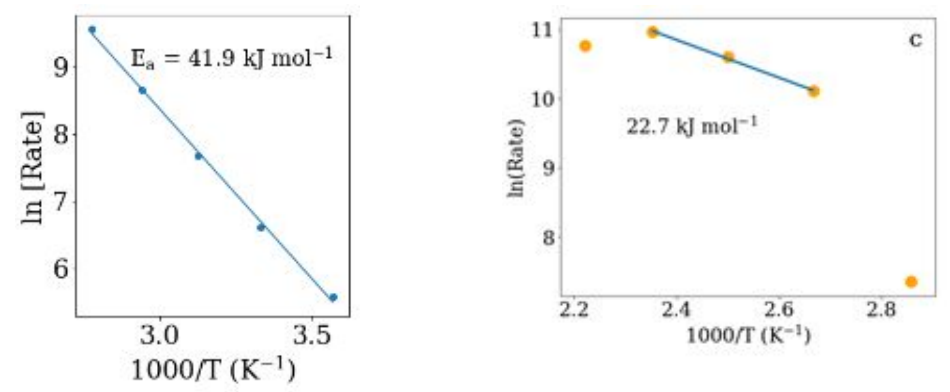

Figure S9. Arrhenius plot from data recorded using Cs-RuBZY10 catalyst (left) and Cs-RuBZY20 catalyst (right) at $p_{\mathrm{H} 2}=7.5$ bar, $p_{\mathrm{N} 2}=2.5$ bar, 10 bar total pressure, $200 \mathrm{~mL} \mathrm{~min}^{-1}$ flow.

As shown in the main manuscript, at the optimal temperature of $425^{\circ} \mathrm{C}$, the highest average values of $x_{\mathrm{H} 2}$ were yielded by BZY20, as well as interestingly not changing at $450^{\circ} \mathrm{C}$. Both of these behaviours have been attributed to increased spill-over resulting in reduce hydrogen poisoning and increased strength of 
binding. The catalyst was tested at additional temperatures down to $350^{\circ} \mathrm{C}$. The data collected using $425^{\circ} \mathrm{C}$ and $450^{\circ} \mathrm{C}$ has been discussed in the main manuscript. For the $50^{\circ} \mathrm{C}$ below $425^{\circ} \mathrm{C}$, the peak rate decreases steadily and $x_{\mathrm{H} 2}$ values approach 0 . This is in agreement with greater poisoning at lower temperatures ${ }^{12}$. In this range, an activation energy can be extracted to be $22.7 \mathrm{~kJ} \mathrm{~mol}^{-1}\left(p_{\mathrm{H} 2}=7.5 \mathrm{bar}\right)$. 
RuBZ

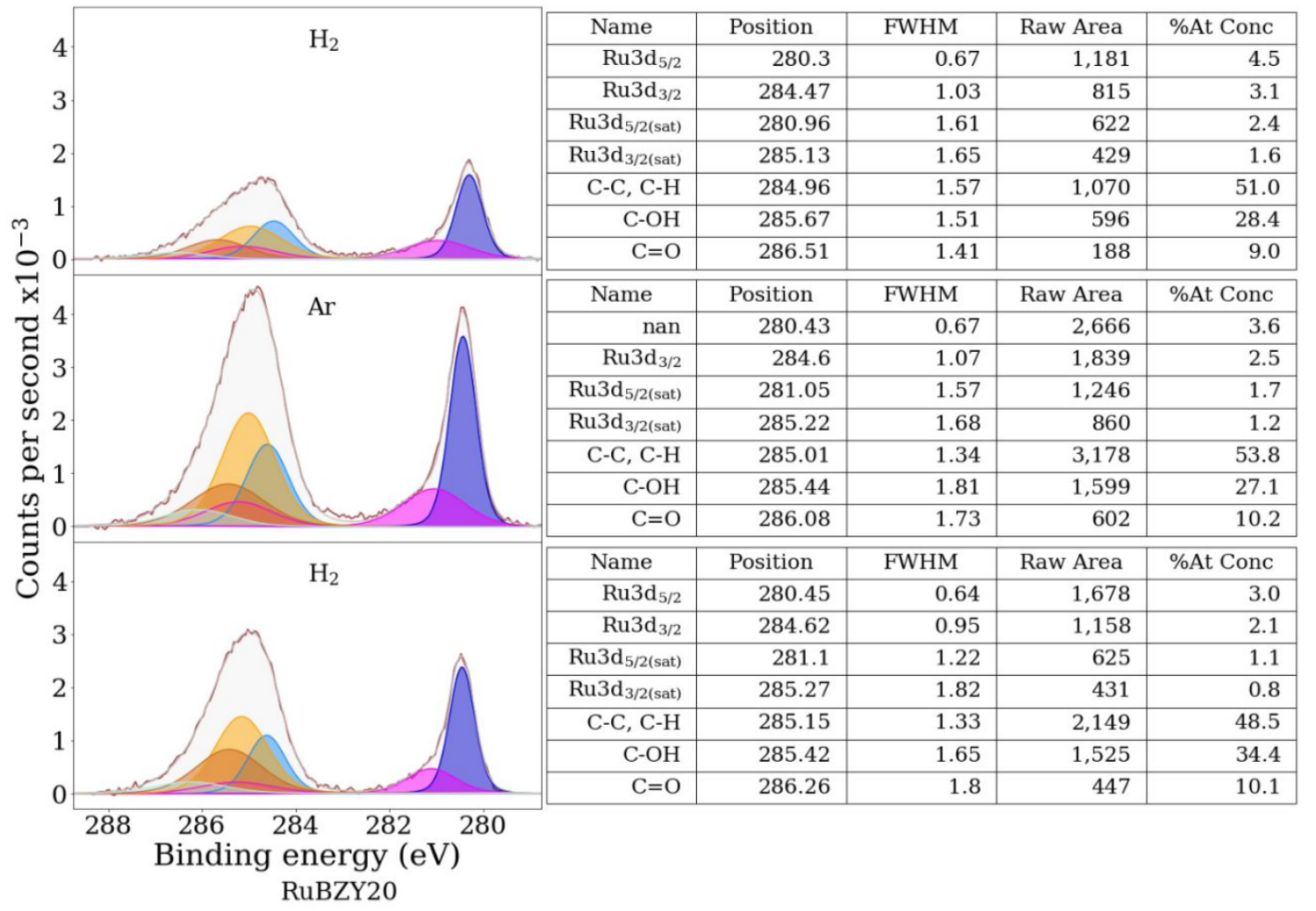

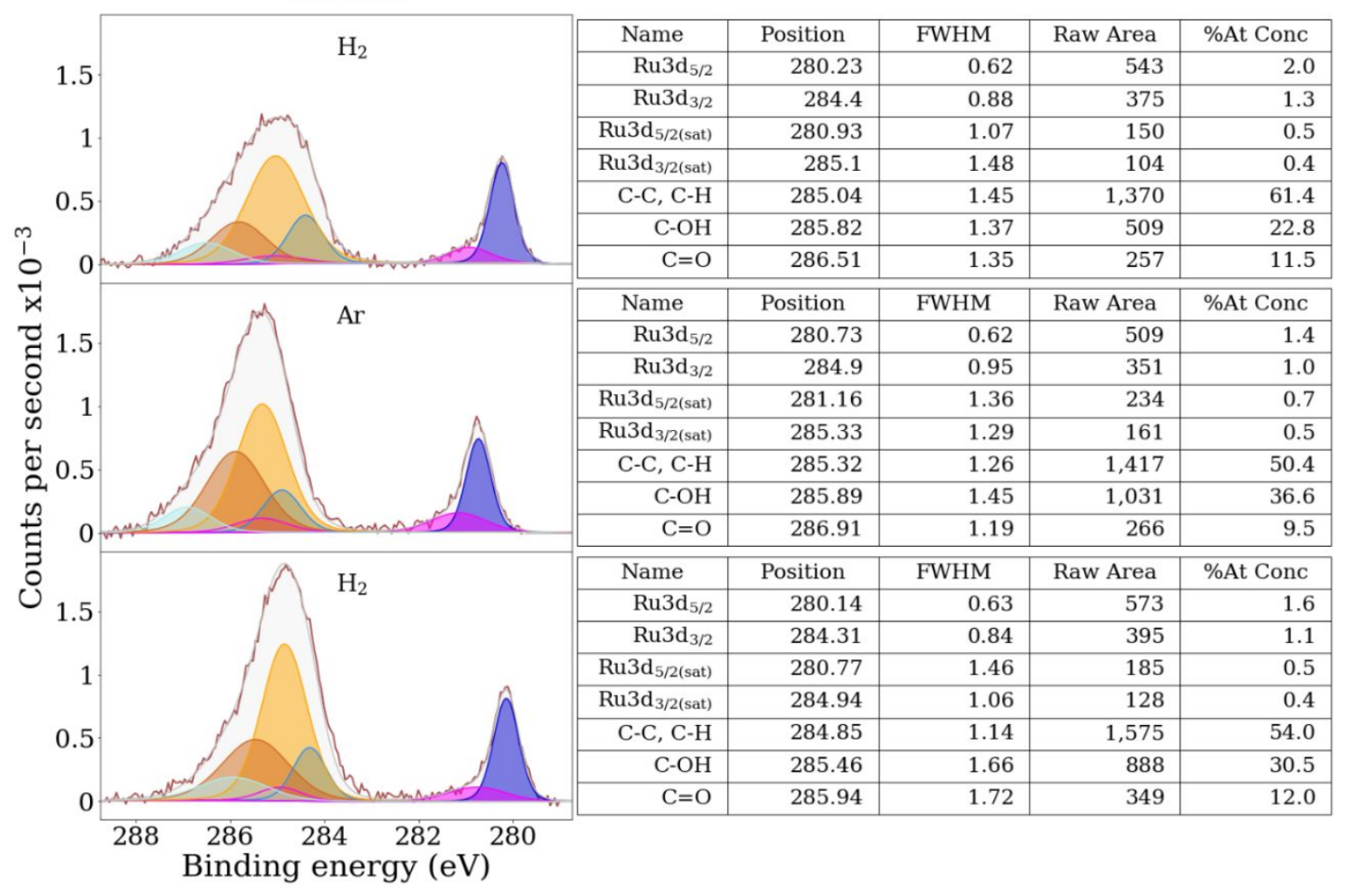



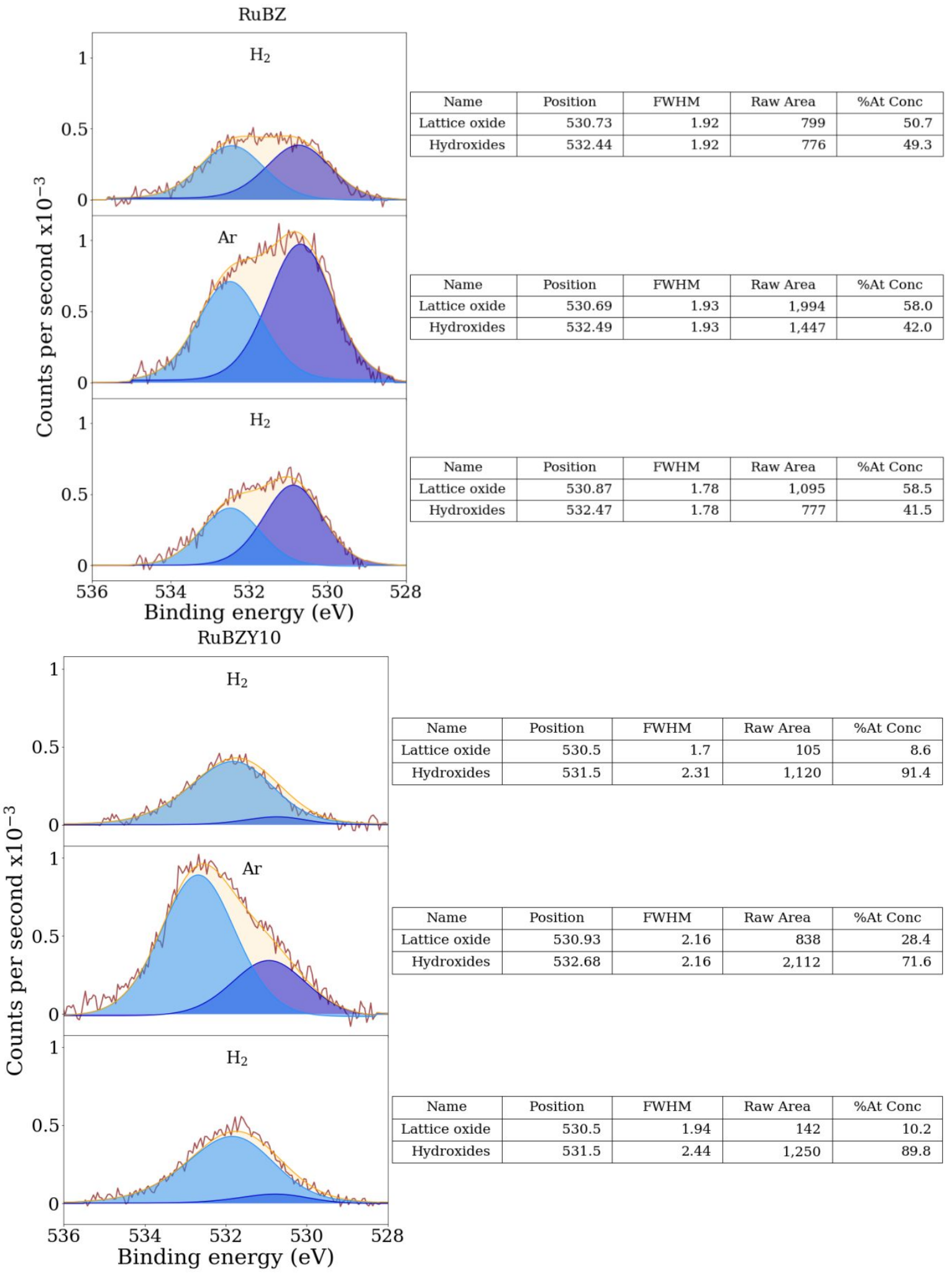

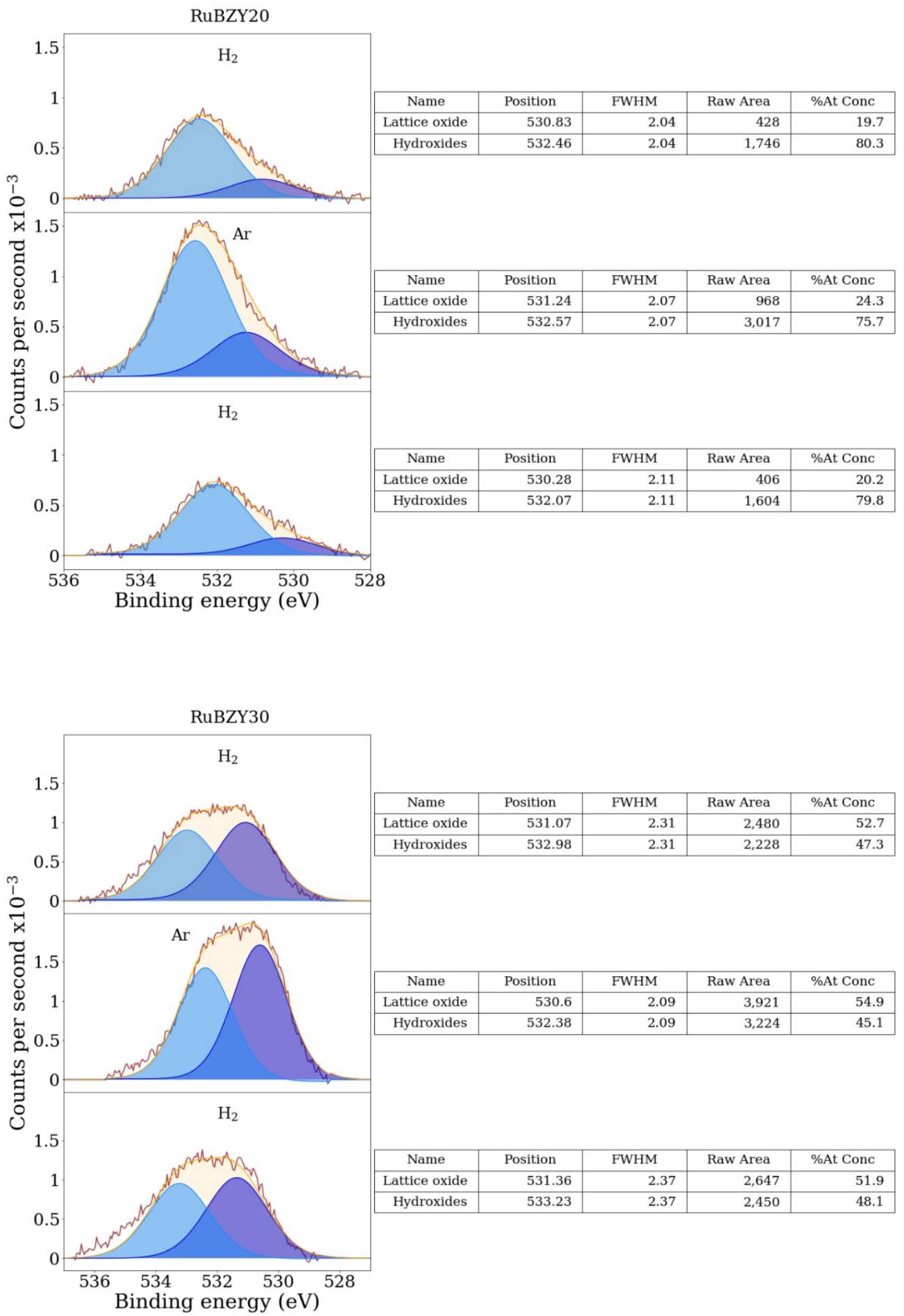

Figure S10. Near-ambient pressure XPS of RuBZY, RuBZY10, RuBZY20, and RuBZY30. 
S14

\begin{tabular}{ccccc}
\hline Sample & Element & $\begin{array}{c}\text { Composition (total) / } \\
\text { \%wt }\end{array}$ & $\begin{array}{c}\text { Composition (support) / } \\
\text { \%wt }\end{array}$ & $\begin{array}{c}\text { Calculated B-site } \\
\text { occupancy / \% }\end{array}$ \\
\hline \multirow{2}{*}{ RuBZ (pre) } & $\mathrm{Ru}$ & 6.569 & $\mathrm{~N} / \mathrm{A}$ & \\
& $\mathrm{Y}$ & 0.005 & 0.005 & \\
\multirow{2}{*}{ RuBZY20 (pre) } & $\mathrm{Ru}$ & 8.203 & $\mathrm{~N} / \mathrm{A}$ & 19.39 \\
& $\mathrm{Y}$ & 5.732 & 6.244 & \\
\multirow{2}{*}{ RuBZY20 (post) } & $\mathrm{Ru}$ & 9.974 & N/A & 20.06 \\
& $\mathrm{Y}$ & 5.896 & 6.549 & \\
\hline
\end{tabular}

Table S2. Catalyst composition from ICP-OES analysis (Optima 8300DV).

\begin{tabular}{|c|c|c|c|c|c|c|c|}
\hline & Treatment & Non-deuterated & & Deuterated & & & \\
\hline & Refinement model & & & No deuterium & & Deuterium & \\
\hline \multirow[t]{2}{*}{ Phase } & Material & BZY20 & RuBZY20 & D-BZY20 & D-RuBZY20 & D-BZY20 & D-RuBZY20 \\
\hline & No. bkg. parameters & \multicolumn{6}{|c|}{24} \\
\hline \multirow[t]{24}{*}{ BZY support } & $R_{\exp } / \%$ & 0.5782 & 0.6366 & 0.7018 & 0.6135 & 0.7015 & 0.6134 \\
\hline & $R_{\mathrm{wp}} / \%$ & 3.8735 & 2.8981 & 4.6343 & 3.3552 & 4.5542 & 3.3078 \\
\hline & $R_{\mathrm{p}} / \%$ & 2.5376 & 2.1157 & 3.1432 & 2.4649 & 3.1944 & 2.3635 \\
\hline & GoF & 6.6992 & 4.5526 & 6.6039 & 5.4685 & 6.4918 & 5.3930 \\
\hline & Space group & \multicolumn{6}{|c|}{$P m-3 m$} \\
\hline & Lattice parameter & & & & & & \\
\hline & $a / \AA$ & $4.22585(7)$ & $4.2229(1)$ & $4.2340(1)$ & $4.2304(1)$ & $4.2341(1)$ & $4.2304(1)$ \\
\hline & Volume / $\AA^{3}$ & $75.464(4)$ & $75.307(6)$ & $75.903(5)$ & $75.710(7)$ & $75.905(5)$ & $75.709(6)$ \\
\hline & Phase density $/ \mathrm{g} \mathrm{cm}^{-3}$ & $5.93(4)$ & $6.0878(5)$ & $5.92(5)$ & $6.0554(5)$ & $5.81(4)$ & $6.059(1)$ \\
\hline & Atomic positions & & & & & & \\
\hline & A site $\left(\mathrm{Ba}^{2+}\right)$ & \multicolumn{6}{|c|}{$(0,0,0)$} \\
\hline & B site $\left(\mathrm{Zr}^{4+} / \mathrm{Y}^{3+}\right)$ & \multicolumn{6}{|c|}{$(0.5,0.5,0.5)$} \\
\hline & $\mathrm{O}^{2-}$ site & \multicolumn{6}{|c|}{$(0.0,0.5,0.5)$} \\
\hline & $\mathrm{D}^{+}$site & \multicolumn{2}{|c|}{$\mathrm{N} / \mathrm{A}$} & \multicolumn{2}{|c|}{$\mathrm{N} / \mathrm{A}$} & \multicolumn{2}{|c|}{$(0,0,0.5)$} \\
\hline & $\mathrm{Ba}^{2+}$ & \multicolumn{2}{|c|}{$1.00(1)$} & \multicolumn{2}{|c|}{$\frac{1}{1.00(1)}$} & \multicolumn{2}{|c|}{$0.98(1)$} \\
\hline & $\mathrm{Zr}^{4+}$ & \multicolumn{2}{|c|}{$0.790(6)$} & \multicolumn{2}{|c|}{$0.775(6)$} & \multicolumn{2}{|c|}{$0.778(6)$} \\
\hline & $\mathrm{Y}^{3+}$ & \multicolumn{2}{|c|}{$0.190(5)$} & \multicolumn{2}{|c|}{$0.176(6)$} & \multicolumn{2}{|c|}{$0.151(6)$} \\
\hline & $\mathrm{O}^{2-}$ & \multicolumn{2}{|c|}{$0.90(1)$} & \multicolumn{2}{|c|}{$1.00(1)$} & \multicolumn{2}{|c|}{$0.97(1)$} \\
\hline & $\mathrm{D}^{+}$ & \multicolumn{2}{|c|}{$\mathrm{N} / \mathrm{A}$} & \multicolumn{2}{|c|}{ N/A } & $0.037(13)$ & $0.048(16)$ \\
\hline & $\underline{b e q}\left(=8 \pi^{2} \times U_{\text {iso }}\right) / \AA^{2}$ & & & & & & \\
\hline & A site $\left(\mathrm{Ba}^{2+}\right)$ & \multicolumn{2}{|c|}{$\frac{1}{1.01(6)}$} & \multicolumn{2}{|c|}{$0.80(7)$} & & \\
\hline & B site $\left(\mathrm{Zr}^{4+} / \mathrm{Y}^{3+}\right)$ & & & & & & \\
\hline & $\mathrm{O}^{2-}$ site & & & & & & \\
\hline & $\mathrm{D}^{+}$site & & & & & & \\
\hline Ruthenium metal & Space group & N/A & $\mathrm{P}_{3} / \mathrm{mmc}$ & $\mathrm{N} / \mathrm{A}$ & $\mathrm{P}_{3} / \mathrm{mmc}$ & $\mathrm{N} / \mathrm{A}$ & $\mathrm{P}_{3} / \mathrm{mmc}$ \\
\hline & Lattice parameter & & & & & & \\
\hline & $a / \AA$ & $\mathrm{N} / \mathrm{A}$ & $2.697(2)$ & N/A & $2.695(2)$ & N/A & $2.694(2)$ \\
\hline & $c / \AA$ & N/A & $4.289(8)$ & $\mathrm{N} / \mathrm{A}$ & $4.307(8)$ & $\mathrm{N} / \mathrm{A}$ & $4.310(7)$ \\
\hline & Volume $/ \AA^{3}$ & $\mathrm{~N} / \mathrm{A}$ & $27.03(6)$ & N/A & $27.09(6)$ & $\mathrm{N} / \mathrm{A}$ & $27.09(5)$ \\
\hline & Ru atomic position & N/A & $(1 / 3,2 / 3,0.25)$ & N/A & $(1 / 3,2 / 3,0.25)$ & $\mathrm{N} / \mathrm{A}$ & $(1 / 3,2 / 3,0.25)$ \\
\hline & Ru occupancy & $\mathrm{N} / \mathrm{A}$ & $1 *$ & N/A & $1 *$ & N/A & $1 *$ \\
\hline & Ru $b e q / \AA^{2}$ & N/A & $1 *$ & N/A & $1 *$ & $\mathrm{~N} / \mathrm{A}$ & $1 *$ \\
\hline
\end{tabular}

Table S3. Details for the Rietveld refinement of deuterated BZY20 and deuterated RuBZY20, with and without an interstitial deuterium site. Parameters fixed at unity denoted by *. 


\section{$\underline{\text { Mechanistic considerations }}$}

We have previously studied the rate equation for ammonia synthesis by examining the reaction orders of $\mathrm{N}_{2}$ over $\mathrm{Ru}$ on different supports, which show almost the same positive order (around 1 to 1.5 ) in the rate equation for ammonia synthesis over ruthenium catalysts as similar to typical literature value. ${ }^{10}$ The value indicates the dynamic adsorption of $\mathrm{N}_{2}$ is critically important in the rate-determining step (dissociative adsorption mechanism). It was found that the reaction order of $\mathrm{H}_{2}$ can be greatly altered from typical negative or zero order $\left(\mathrm{H}_{2}\right.$ poisoned $\left.\mathrm{Ru}\right)$ on inert supports to positive order (rate dependent on $\left.\mathrm{H}_{2}\right)$ if some hydrogen-trapped supports are used.

In this paper, we have focussed on the correlation of the rate for ammonia production with the proton concentration (proton trap site) on the BYZ support with the $\mathrm{H}_{2}$ reaction order. First, we consider a $\mathrm{Ru}$ metal surface that could be under dynamic equilibrium with gaseous $\mathrm{H}_{2}$ (classical Langmuir-Hinshelwood) and the surface hydrogen traps on the support if slow may not be able to alter such process under steadystate conditions. On the other hand, the kinetics for hydrogen adsorption on metal can still be altered provided that there is a faster but reversible hydrogen traps/storage on the support. Kitano et al. have recently studied the kinetics of nitrogen and hydrogen isotope exchange and hydrogen adsorption/desorption reactions over $\mathrm{Ru} / \mathrm{C} 12 \mathrm{~A} 7: \mathrm{e}^{-15}$ They concluded that the rate-determining step of ammonia synthesis involves rapid but reversible storage and release of hydrogen atoms on the $\mathrm{Ru} / \mathrm{C} 12 \mathrm{~A} 7: \mathrm{e}^{-}$ surface on the basis of observed hydrogen absorption/desorption kinetics.

In addition, as shown from the Fig. 5, we doped Y into BZ which would increase the concentration of oxygen vacancies. However, we did not see the progressive linear relationship of rate versus doping (oxygen vacancies) concentration but was found to be optimum at $20 \% \mathrm{Y}$, afterwards declining. There appears to be no simple direct relationship between the oxygen vacancies of the support and the weakening of hydrogen adsorption on $\mathrm{Ru}$. We also observed the effect of hydrogen trapping near $\mathrm{Y}$ by our neutron work. As a result, we adopted a similar view as Kitano et al., that the surface traps on the support can affect the adsorption kinetics of the overlying Ru. However, further proof is required in future through the careful 
study of adsorption heat and saturation coverage of hydrogen, and temperature-programmed desorption measurements.

Notice that there appears to be no initial rate or directional limitations as anticipated for homogeneous $\mathrm{Ru}$ sites on a single crystalline support surface. However, for polycrystalline powder catalysts with randomly distributed ruthenium, there are facets of the Ru metal crystallites and BYZ support that show different relative adsorption for $\mathrm{H}_{2}$ and $\mathrm{N}_{2}$. For example, hydrogen poisoning for more active $\mathrm{Ru}$ facets can be alleviated by conducting the $\mathrm{H}_{2}$ species to other facets with weaker adsorption for reversible $\mathrm{H}_{2}$ desorption via the support and its local proton conductivity. The $\mathrm{H}_{2}$ reservoir and the fast reversible $\mathrm{H}_{2}$ storage and dissociation from the BYZ perovskite will then help the overall $\mathrm{H}_{2}$ poisoning over the overlying $\mathrm{Ru}$ under dynamic conditions. In these catalytic investigations we particularly used continuous flow reactors, the dynamic equilibrium in which strong $\mathrm{Ru}$ active sites are made available to dinitrogen adsorption more often than without the proton reservoir can be obtained. 


\section{$\underline{\text { References }}$}

(1) Han, D.; Shinoda, K.; Sato, S.; Majima, M.; Uda, T. Correlation between Electroconductive and Structural Properties of Proton Conductive Acceptor-Doped Barium Zirconate. J. Mater. Chem. A 2014, 3 (3), 1243-1250. https://doi.org/10.1039/C4TA05701E.

(2) Kitano, M.; Inoue, Y.; Sasase, M.; Kishida, K.; Kobayashi, Y.; Nishiyama, K.; Tada, T.; Kawamura, S.; Yokoyama, T.; Hara, M.; Hosono, H. Self-Organized Ruthenium-Barium Core-Shell Nanoparticles on a Mesoporous Calcium Amide Matrix for Efficient Low-Temperature Ammonia Synthesis. Angew. Chem. 2018, 130 (10), 2678-2682. https://doi.org/10.1002/ange.201712398.

(3) Kitano, M.; Inoue, Y.; Yamazaki, Y.; Hayashi, F.; Kanbara, S.; Matsuishi, S.; Yokoyama, T.; Kim, S.-W.; Hara, M.; Hosono, H. Ammonia Synthesis Using a Stable Electride as an Electron Donor and Reversible Hydrogen Store. Nat Chem 2012, 4 (11), 934-940. https://doi.org/10.1038/nchem.1476.

(4) Wang, Z.; Liu, B.; Lin, J. Highly Effective Perovskite-Type BaZrO3 Supported Ru Catalyst for Ammonia Synthesis. Applied Catalysis A: General 2013, 458, 130-136. https://doi.org/10.1016/j.apcata.2013.03.037.

(5) Sato, K.; Imamura, K.; Kawano, Y.; Miyahara, S.; Yamamoto, T.; Matsumura, S.; Nagaoka, K. A Low-Crystalline Ruthenium Nano-Layer Supported on Praseodymium Oxide as an Active Catalyst for Ammonia Synthesis. Chem. Sci. 2016, 8 (1), 674-679. https://doi.org/10.1039/C6SC02382G.

(6) Shimoda, N.; Kimura, Y.; Kobayashi, Y.; Kubota, J.; Satokawa, S. Ammonia Synthesis over YttriumDoped Barium Zirconate and Cerate-Based Perovskite-Type Oxide Supported Ruthenium Catalysts. International Journal of Hydrogen Energy 2017, 42 (50), 29745-29755. https://doi.org/10.1016/j.ijhydene.2017.10.108.

(7) Wang, P.; Chang, F.; Gao, W.; Guo, J.; Wu, G.; He, T.; Chen, P. Breaking Scaling Relations to Achieve Low-Temperature Ammonia Synthesis through LiH-Mediated Nitrogen Transfer and Hydrogenation. Nature Chemistry 2017, 9 (1), 64-70. https://doi.org/10.1038/nchem.2595.

(8) Ogura, Y.; Sato, K.; Miyahara, S.; Kawano, Y.; Toriyama, T.; Yamamoto, T.; Matsumura, S.; Hosokawa, S.; Nagaoka, K. Efficient Ammonia Synthesis over a Ru/La 0.5 Ce 0.5 O 1.75 Catalyst Pre-Reduced at High Temperature. Chemical Science 2018, 9 (8), 2230-2237. https://doi.org/10.1039/C7SC05343F.

(9) Lin, B.; Liu, Y.; Heng, L.; Wang, X.; Ni, J.; Lin, J.; Jiang, L. Morphology Effect of Ceria on the Catalytic Performances of $\mathrm{Ru} / \mathrm{CeO} 2$ Catalysts for Ammonia Synthesis. Ind. Eng. Chem. Res. 2018, 57 (28), 9127-9135. https://doi.org/10.1021/acs.iecr.8b02126.

(10) Wu, S.; Peng, Y.-K.; Chen, T.-Y.; Mo, J.; Large, A.; McPherson, I.; Chou, H.-L.; Wilkinson, I.; Venturini, F.; Grinter, D.; Ferrer Escorihuela, P.; Held, G.; Tsang, S. C. E. Removal of Hydrogen Poisoning by Electrostatically Polar MgO Support for Low-Pressure NH3 Synthesis at a High Rate over the $\mathrm{Ru}$ Catalyst. ACS Catal. 2020, 10 (10), 5614-5622. https://doi.org/10.1021/acscatal.0c00954.

(11) Ozaki, A.; Taylor, H.; Boudart, M. Kinetics and Mechanism of the Ammonia Synthesis. Proceedings of the Royal Society of London Series A 1960, 258, 47-62. https://doi.org/10.1098/rspa.1960.0174.

(12) Rosowski, F.; Hornung, A.; Hinrichsen, O.; Herein, D.; Muhler, M.; Ertl, G. Ruthenium Catalysts for Ammonia Synthesis at High Pressures: Preparation, Characterization, and Power-Law Kinetics. Applied Catalysis A: General 1997, 151 (2), 443-460. https://doi.org/10.1016/S0926860X(96)00304-3.

(13) Shimizu, H.; Christmann, K.; Ertl, G. Model Studies on Bimetallic Cu/Ru Catalysts: II. Adsorption of Hydrogen. Journal of Catalysis 1980, 61 (2), 412-429. https://doi.org/10.1016/00219517(80)90388-7.

(14) Shetty, S.; Jansen, A. P. J.; van Santen, R. A. Active Sites for N2 Dissociation on Ruthenium. J. Phys. Chem. C 2008, 112 (46), 17768-17771. https://doi.org/10.1021/jp8085478.

(15) Kitano, M.; Kanbara, S.; Inoue, Y.; Kuganathan, N.; Sushko, P. V.; Yokoyama, T.; Hara, M.; Hosono, H. Electride Support Boosts Nitrogen Dissociation over Ruthenium Catalyst and Shifts the Bottleneck in Ammonia Synthesis. Nat Commun 2015, 6 (1), 6731. https://doi.org/10.1038/ncomms7731. 
